\title{
Navigating Tensions: Education Policy and the Science Teacher $^{1}$
}

\section{Tensões da Jornada: Políticas Educacionais e o Professor de Ciências}

\author{
Jim Ryder ${ }^{\circledR}$ United Kingdom
}

Teachers of science are constantly experiencing changing education policies that impact on their daily working lives, e.g. a national or state-wide requirement to teach about the nature of science, or a school-wide requirement to use student peer assessment in the classroom. Such policies typically come 'from outside'; they are not decisions made by individual teachers or small groups of teachers. They also come with authority and, often, powerful mechanisms of accountability, e.g. national assessment of student learning outcomes or teacher appraisal programmes. Teaching involves navigating these shifting policy environments whilst practising personal identity and associated beliefs about teaching. This results in many challenges, but also opportunities, for teachers. This paper elaborates on the form and role of education policy and what this means for teachers of science. Drawing upon studies of how science teachers experience education policy, the contexts of teachers' work are characterised in terms of personal, internal (to school), and external themes. The paper then suggests features of school policy environments that can support better, and more sustainable, outcomes for teachers and other stakeholders.

Keywords: education policy; curriculum reform; teachers change.

Constantemente, professores de Ciências vivenciam mudanças nas políticas educacionais que impactam suas atividades didáticas diárias. Alguns exemplos são parâmetros nacionais ou estaduais que solicitam que o ensino de Ciências envolva aspectos de Natureza da Ciência, ou decisões de direções de escola relacionadas com avaliações dos estudantes pelos colegas em sala de aula. Tais políticas sempre vêm "de fora"; não são decisões tomadas pelos professores individualmente ou por um pequeno grupo de professores. Elas também chegam ao professor com uma certa autoridade e, frequentemente, são acompanhadas de mecanismos poderosos de prestação de contas como, por exemplo, programas nacionais de avaliação de estudantes ou novos mecanismos de avaliação de professores. Nesse contexto, ensinar requer do professor encontrar uma maneira de lidar com tensões nesses ambientes de mudanças de políticas, ao mesmo tempo em que mantem sua identidade profissional e suas crenças sobre ensino a elas relacionadas. Isto resulta em muitos desafios, mas também oportunidades, 1 This paper is based on a plenary talk given at the ENPEC conference, Águas de Lindoia, Brazil, November 2015. 
para os professores. Este artigo discute as maneiras pelas quais políticas educacionais se apresentam, assim como seus papéis e o que elas podem significar para professores de ciências. A partir de estudos sobre como professores de Ciências vivenciam políticas educacionais, os contextos de trabalho de professores são caracterizados em termos de aspectos pessoais, internos (à escola) e externos. O artigo também sugere características de ambientes de políticas escolares que podem dar suporte a resultados melhores, e mais sustentáveis, para professores e outros envolvidos no processo educacional.

Palavras-chave: Política educacional; reforma curricular; professores em contextos de mudança.

\section{Education policy and the teacher}

Education policy has been characterised as 'the authoritative allocation of values' (Kogan, 1975). Thus, a national or state-wide policy to teach and assess socio-scientific issues (such as climate change or the treatment of genetic diseases) within compulsory schooling carries both authority (school leaders and teachers are expected to 'follow' the policy) and values (someone believes that this is an important thing for all young people to learn about, and perhaps act on). The policy is 'allocated' in that those working in school have not necessarily been involved in deciding that this is an area of the curriculum that needs to be made compulsory, even if many may agree with this as an emphasis. Developing the frame of 'policy' more broadly (i.e. beyond education settings) Colebatch (2009) emphasises how policy involves decisions about what gets noticed, what is seen as important, agenda setting, statement of goals (what we are trying to do), and (crucially) allocation of resources such as funding and sustaining organisations to support/monitor the 'implementation' of the policy.

Furthermore, because science education has many stakeholders there are many education policies and these policies often change as stakeholders (and their authority) shift over time (Fensham, 2009; Ryder \& Banner, 2011). In the case of science education different stakeholders might emphasise: encouraging students to choose science or engineering courses at university (professional scientists and engineers); developing students' ability to think and act creatively to solve problems (employers); develop an interest in, even a passion for science as a subject (scientists, science teachers); attaining good grades in high-stakes attainment tests (politicians, students, parents). Thus, teachers are responding to multiple policies often all at the same time. This can result in tensions, but also alignments, as explored later in this paper. Furthermore, experienced teachers often report a sense of 'policy cycles' in which old policies came back again after a period of time:

I sense the education pendulum here, I do sense it, and I think we've moved away from [subject matter knowledge] but I just sense it will come back again. (Ryder \& Banner, 2013, p. 505). 
Similarly, a recent newspaper blog reported a teacher of English in the UK reflecting:

Every new initiative in education is a reaction to what has preceded it. We had no coursework, then $100 \%$ coursework, then a gradual slimming down, until we got back to where we started: no coursework. We had "chalk and talk", then group work, then developing ideas through discussion, now we're at entertainment through Power Point (which is just a technologically impressive form of chalk and talk). English Language examinations began with comprehension, analysis of grammar and précis, then became focused on creative processes, allowing students time to write at length with bare stimulus, now we're back where we started. What goes around has come around. ${ }^{2}$

It is striking how teachers are 'positioned' in different ways in policy discourse. Teachers can be 'deliverers' of education policy. Their role is to take the policy and 'deliver' it (whole and unchanged) within their working contexts. A 'softer' framing is that of teachers as 'implementers' of education policy, taking the policy (as a whole) and making it happen in their workplace, perhaps with some local adaptations. Softer still might be teachers having the responsibility of policy 'enactment', emphasising the active role teachers have in shaping policy in their local context (Ball, Maguire, \& Braun, 2011). Teachers might also be conceived as 'co-producers' of policy having an equal (or even privileged) role in making policy in their schools and classrooms (Pring et al., 2009). In this latter conceptualisation policy can never be 'pre-formed' and certainly never 'teacher-proof'. Empirical studies of policy enactment within schools have identified these differing roles in action (Coburn, 2004; Cuban, 1995). Thus, teachers can reject or subvert education policies. There can be a surface, or symbolic, responses that relate to the policy but do not result in significant change in teachers' practices. Policies can be assimilated by teachers, with change occurring but the outcomes not strongly reflective of the original policy intentions. These differing metaphors of teachers' roles, and typologies of outcomes, emphasise the variation, fluidity and significance of the process of teacher engagement with education policy.

Teachers serve a range of stakeholders in their local community and beyond: e.g. students, parents, the teaching profession, local community leaders and local/ national groups of employers. The role of education policy is to frame teachers' work as a public service. Typically, policies also include mechanisms for ensuring that teachers are responding appropriately. A neo-liberal framework is increasingly evident in education policy (Smith, 2011). This emphasises the power of 'market' forces in shaping schooling and the role of powerful regulatory mechanisms. In a neo-liberal framework standardised curricula and national testing are required in order to provide appropriate benchmarks for regulatory mechanisms. These mechanisms, operated perhaps through teacher promotion or performance related pay processes, can be used to shape and

2 Secret Teacher: An invasive alien species is taking over education, The Guardian Online, November 2016.http:// gu.com/p/5cxtv?CMP=Share_iOSApp_Other 
monitor teachers' work, making them accountable to policy. However, empirical studies have shown how powerful accountability mechanisms can distort teaching in classrooms and have negative impacts on teachers' sense of professionalism and well-being (Ball, 2003). A neo-liberal frame, with its strongly market-customer based conceptualisation, emphasises mechanisms of accountability and control and arguably de-emphasises the profession of teaching and teacher agency within this. However, there are other ways of thinking about 'appropriate' teacher response to policy. Teachers can be positioned as 'responsible for' policy enactment. Or policy can be seen as a process through which society provides teachers with a 'mandate' to develop their practice in different directions. These frames emphasise teacher agency and suggest a two-way 'social contract' between teachers and the public they serve ${ }^{3}$. They also invite more local, teacher-developed, mechanisms of ensuring teachers respond appropriately to education policy reforms.

In summary, education policy has a major role in the working lives of science teachers and more broadly in the operation of teaching within, and for, society. In the next section the differing elements of this policy network are elaborated in terms of personal, internal and external contexts of teachers' work. The paper ends with recommendations on features of school policy environments that can support better, and more sustainable, outcomes for teachers and other stakeholders.

\section{Personal, internal and external contexts of teachers' work}

Below I refer to a study that I was involved in with colleagues at Leeds (Ryder \& Banner, 2013). The aim is to draw out, in a specific context, the detail of differing influences on the work of teachers and the role of education policy within this. These findings have been corroborated, and extended, in a recent review of 34 international studies of teachers' experiences of externally-driven science curriculum reform (Ryder, 2015).

In 2006 a new national science curriculum for 14-16 year olds was introduced in England. This was arguably the biggest change in the national curriculum for science since its introduction in 1989. The reform emphasised the teaching of socio-scientific issues and the nature of science, alongside the more traditional focus on canonical science knowledge and skills (DCSF/QCA, 2008; Orrow-Whiting, Edwards, \& Slade, 2007). This policy shift was an operationalisation of calls within the UK and beyond for a school science curriculum that supported 'scientific literacy' for all students, alongside science education as a preparation for post-compulsory science education (for a minority of students) (Millar \& Osborne, 1998; Roberts \& Bybee, 2014). Given the significance of this curriculum policy shift it was likely to have a significant impact on the work of teachers. The outcomes of this reform were examined as part of a three year longitudinal study: the Enactment and Impact of Science Education Reform (EISER) study. A designed sample of 22 teachers from 19 schools in England were interviewed in each of three years to explore their experiences of the reforms. These interviews were

3 These ideas are drawn from discussions held with attendees at ENPEC 2015. 
held from 2008-2011, thereby focusing on teachers' experiences within the third, fourth and fifth years of the reform. Analysis of these interviews identified 15 influences on teachers' responses to the reforms. These influences were characterised in terms of personal factors (e.g. teacher subject knowledge, beliefs and goals), internal contexts of their school environment (e.g. departmental leadership practices) and factors external to the school (e.g. accountability through national student attainment measures). This personal, internal, external framing was drawn from Ivor Goodson's biographical work on the professional lives of teachers (Goodson, 2003). Figure 1 provides an overview of these factors, presented as a 'policy network' within which teachers negotiate their response to the curriculum reform alongside a wide range of other policies, influences and contextual factors.
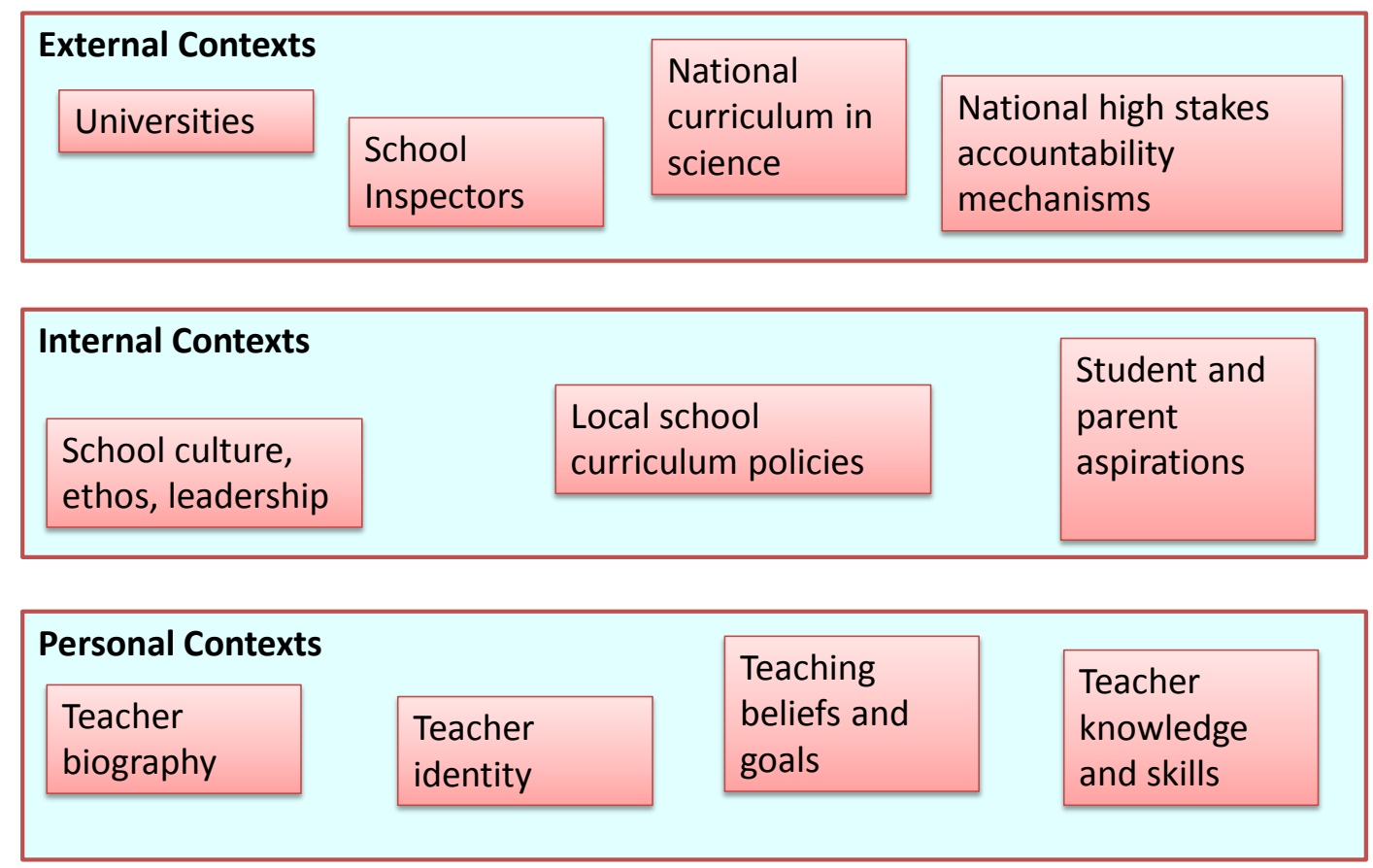

Figure 1. Teacher response to education policy reform; navigating a complex network of influences, stakeholders, multiple policies and contextual factors.

Figure 1 emphasises the ongoing complexity of teachers' work and the inevitable role of policy within this. The factors in Figure 1 are dynamic, and come in and out of focus at different times, in often unpredictable ways. The work of the teacher involves constantly negotiating these shifting, and often competing influences. In the next section I draw upon other empirical studies to examine details of the process, and outcomes, of teachers' work within this policy network.

\section{Navigating the policy network}

Working within this complex policy network inevitably results in tensions. Jeffrey and Woods (1998) studied teachers' experiences of high stakes external inspection within 
six primary schools in the England. One of the teachers in this study, Diane, reflected:

My first reaction was 'I'm not going to play the game', but I am and I know they know I am. I don't respect myself for it; my own self respect goes down. Why aren't I making a stand? Why aren't I saying, 'I know I can teach; say what you want to say', and so I lose my own self-respect. I know who I am; I know why I teach, and I don't like it; I don't like them doing this, and that's sad, isn't it? (Jeffrey \& Woods, 1998, p.160).

In this policy context 'playing the game' involved enacting the emphases within the official school inspection framework in the classroom: traditional transmission approaches to teaching and ongoing formal assessment of student learning. For Diane a powerful mechanism of external authority over her practice (formal school inspection) resulted in pressures that conflicted with her personal teaching values and goals, resulting in challenges to her own identity as a teacher, demoralisation and negative stress.

Lunn and Solomon (2000) studied English primary school teachers' experiences of the first introduction of a national curriculum in science; a policy shift that included the requirement to conduct practical work. The following quote from a teacher, Florence, shows her frustration at the lack of autonomy in the face of what she saw as an overly prescriptive externally imposed science curriculum:

[before the reform] if you were particularly interested in something I felt I had the freedom to follow it up... I now feel I've lost that freedom" (Lunn \& Solomon, 2000, p. 1050).

The freedom to pursue different areas of science came from her own love of the subject, and also the responses of her students:

It would be nice to have a free hand so that if they became particularly interested in one particular aspect of something, you could then follow that, without having the constraints of the curriculum or an examination syllabus to pull you back in line (Lunn \& Solomon, 2000, p. 1051).

Again, for Florence, there is no easy balance here between her personal goals to communicate her love of science and respond to the interests of her students, and external demands to follow a prescribed science curriculum.

Donnelly et al. (1996) provide another example of teacher responses to reform being led by external forces. In a study of teachers' experiences of the introduction of a national curriculum and assessment theme focussed on 'science investigations' they find that:

'Teachers' comments largely [transferred] authority over the substance of their work in the classroom and laboratory, and the directions of its development, to others. (Donnelly et al., 1996).

They report that teachers often appeared diffident about their work, seeking guidance on the enactment of the reform from external experts. In contrast to the two earlier examples of Diane and Florence, who both reported that they felt their autonomy had been removed by the external reform, several of the teachers in the study by Donnelly 
et al. appear to relinquish agency over their workplace practices and are seeking clearer guidance from others.

In all three of the cases above it is clear that an appropriate balance between responsibility for the enactment of policy and local autonomy has not been attained. Below I refer to two studies which provide a more positive sense of teacher agency. These studies point towards the features of policy contexts likely to support teachers as they navigate multiple influences in their working lives.

Carolyn Wallace (2012) uses a personal account of her experiences as a secondary school teacher in the US to highlight two distinct 'genres' of curriculum policy texts. Taking a one year break from academia she worked as a biology teacher in the state of Georgia. There she found herself enacting a detailed, authoritarian, non-participatory curriculum policy text. Learning outcomes for students were presented in detail; what counted as 'mastery' in biology for students at this age was presented 'fully formed' to the teacher. For example, here is one learning objective for 14-year-olds: 'determine the heat capacity of a substance using mass, specific heat and temperature.' The language of these curriculum standards was one of 'content and product'. Learning performance was disconnected from teaching methods. Wallace reports that she felt that her personal goals to engage her students in meaningful enquiry activities in the classroom were challenged by this authoritarian curriculum text. She contrasts this curriculum genre with that of the national curriculum in New Zealand introduced in 2007. This curriculum text was much more open-ended, and provided 'space' for the teacher to adapt to local contexts and personal goals. The language of these curriculum standards was more 'process-oriented'. The nature of successful performance was more open, with emphasis placed on linking science content objectives with reasoning processes such as describing patterns, explaining and investigating. For example, here is one physics objective olds within the New Zealand curriculum for 14-year-oldswithin the theme of 'using physics': 'explore a technological or biological application of physics'. This curriculum genre invites teachers to exercise discretionary judgment whilst remaining responsible for the direction proscribed within the national curriculum policy text. Wallace's account is consistent with the call by Edgar Jenkins to recognise the different forms of educational policy, and their consequences for policy enactment in schools (Jenkins, 2013).

Wallace and Priestley (2011) provide a second example of a study highlighting a policy context supportive of teachers' professional learning. As part of a larger study they examine the experiences of one secondary school science teacher, Vanessa, over a single year. Vanessa is responding to two linked policy reforms in Scotland: a national reform encouraging numeracy across the curriculum and a regional reform promoting the use of 'assessment for learning' strategies (p. 368). From the outset, within the planned enactment activities, there is an explicit link made between two distinct policies that this teacher is involved with. This appears to be a rare example of attempting 'policy coherence' (Oates, 2011) from the teacher's perspective. More frequently, policy makers (and often researchers and professional development leaders) tend to focus on 'their' 
curriculum development package or policy, with less regard for how this intervention might be interacting strongly with many other policy interventions experienced by the teacher. Over a period of a year Vanessa worked in a network of 10-20 science teachers from different schools who met regularly. This 'associated schools group' was supported by a university researcher. Within this group Vanessa was encouraged to engage in a wide range of reform activities associated with the twin reforms. Crucially she was assigned significant autonomy to decide the focus of these activities; they were not prescribed. Thus, within the broad policy remit of numeracy links and assessment for learning, Vanessa was able to trial specific activities (e.g. different forms of peer assessment) as appropriate to her students and her school context. She valued the opportunity to interact with other teachers (over a significant period) to share her developing experiences of responding to the reforms. Several features of this case point to policy contexts that can promote teachers' professional learning: an explicit attempt to provide policy coherence, working from the teacher's perspective; external 'resources' to support teachers' responses (e.g. the university lecturer); long term support; encouragement to exercise local autonomy whilst working within a broad policy remit; and the opportunity to share experiences with teachers from other school contexts. Taken together we can see here strong enactments of both responsibility (to the policy, to the teacher community, to students and the local community) and teacher authority and agency over the local detail of their classroom activities.

\section{Policy mechanisms to support teachers' professional learning}

The empirical studies reviewed above suggest features of policy contexts likely to support teachers in engaging with external education policy. The starting point is to recognise 'policy' from a teacher's perspective. This is what Figure 1 attempts to capture. Take the example of the introduction of socio-scientific issues within a national curriculum. Teachers are, in some way, responsible for responding appropriately to this curriculum reform. However, at the same time, they are also responsible to the many other reforms and stakeholders represented in Figure 1. Thus, teachers need to introduce approaches to teaching socio-scientific issues in their classroom, but in doing so they need to take account of how such teaching relates to national inspectorate expectations, its impact on student attainment as monitored both within school and also via national examinations (are socio-scientific issues represented in these examinations, and if so how?), how different students respond to such teaching and how all of this activity relates to their personal beliefs and goals as teachers. Given this complexity, policy contexts should seek coherence across distinct policies. Those responsible for developing policy reforms should ask how an individual reform interacts with other reforms being experienced by teachers. Pursuing our example of socio-scientific issues, policy makers could ensure that socio-scientific issues are recognised as valuable by the national school inspectorate and that socio-scientific issues feature appropriately within national examinations. 
The potential to exercise local flexibility in the enactment of policy reforms is crucial. Each individual teacher has his or her own version of Figure 1. There may be commonalities across external contexts, but variation soon emerges within internal school contexts ${ }^{4}$ and further still within the personal biographies and beliefs of the teacher. In principle all teachers cannot enact a curriculum reform in the same way. Good teaching involves enacting the core features of the curriculum reform but adapting these as appropriate to local contexts. The analysis by Wallace introduced earlier shows that the 'genre' of a curriculum reform can either support or constrain this process. Detailed, authoritarian curriculum texts leave little room for local adaptation and therefore constrain teacher responses. What is needed is an over-arching policy, with core principles, but with sufficient scope to enable the exercise of local flexibility - as in the curriculum examples from the New Zealand reforms provided by Wallace.

We have also seen that the exercise of local flexibility can be supported through local mechanisms of 'policy brokering. From the example in Scotland introduced earlier, the inclusion of a university researcher as part of the 'associated schools groups' enabled teachers to interact over time with someone with detailed knowledge of a reform and associated scholarship (Wallace \& Priestley, 2011). The teachers involved were able to ask questions, arising from their work in local contexts, as they enacted reforms. The associated school groups are an example of a 'policy lever' (Ball, 2003). They represent a designed (and resourced) activity that supports the appropriate enactment of the policy in local contexts. Such policy levers need to be an expected feature of any educational policy reform. Alongside reform aims, principles and texts, there needs to be explicit consideration of mechanisms that will support its enactment. Crucially, these mechanisms need to be well-resourced, locally available, and long-term (i.e. several years).

The example of the 'associated school groups' also shows how teachers can be encouraged to take control of their enactment of policy; working against a focus on external monitoring of teachers, towards a 'social contract' model in which teachers actively exercise responsibility for society demands on their role in schools. Rather than choosing from an externally produced 'catalogue' of available professional development courses, many of these teachers were developing a personalised programme of professional development, appropriately resourced, based on their ongoing enactment of curriculum and assessment reforms. This is surely the goal of 'professional learning'. At a policy level, such autonomy over professional development can be encouraged. For example, evidence of a proactive approach to professional development can be incorporated within teacher appointment criteria. Accreditation of professional development can require this proactive approach over time. In addition, national and local funding can be provided to support such activities.

4 Within England the increasing role of 'school clusters', with growing resourcing and leadership autonomy, is resulting in policy contexts with powerful 'internal' local school system policies. Arguably, these are open to sharper, and less accountable, policy shifts that impact heavily on the work of teachers. 


\section{Conclusion}

It is crucial that policy makers recognise that the form of their policies, and the genre of associated policy texts, carry implicit messages about the role of teachers in policy enactment. Based on the outcomes of empirical studies, it is argued here that policies aimed at supporting professional learning need to promote an appropriate balance between responsibility and autonomy in science teachers' work. Features of policy contexts likely to support this balance include: recognising the multiple policies to which teachers are responding; seeking coherence across these policies; enabling (indeed requiring) the exercise of local flexibility in the enactment of teacher development policies; and building structures that encourage teachers to take control of their professional development. Overall, whilst it is important to consider the detail of teachers' knowledge and skills as enacted within the classroom, greater consideration needs to be given to the broader social and political contexts of their work.

The 2013 yearbook of the Consortium of Institutions for Development and Research in Education in Europe (CIDREE) provides an overview of policy contexts in 13 countries across Europe (Kuiper \& Berkvens, 2013). The yearbook editors describe the outcome as 'a curricular smorgasbord' (p. 14) of different, and shifting, regulation and de-regulation policy contexts. In some countries there is a shift towards stronger 'output' regulation via national assessment policies (e.g. Sweden). Other countries are introducing stronger 'input' regulation via highly prescriptive curricula goals and content (e.g. Norway). Most countries make policy reference to the centrality of teachers, but the degree of 'space' for local teacher autonomy designed into curriculum reforms varies widely. Interestingly, given its common policy positioning as a 'high performing' educational system, Finland has a distinctive policy context that emphasises:

intensive cooperation between national and local levels with teachers in the key role as experts, trust in teachers and local authorities, and engaging stakeholders in a productive dialogue in order to create and maintain a balance between the national core curriculum, local curricula and school-specific learning plans. Finland does not have educational control systems like a school inspectorate or national achievement tests covering entire age groups. Instead, school self-assessments and sample evaluations inform curriculum enactment and improvement. (Kuiper \& Berkvens, 2013, p. 10)

Here we see many of the features of policy contexts to support teachers advocated in this paper; there is balance here between responsibility to multiple stakeholders and local teacher autonomy. This provides a positive message and motivation that it is possible to work towards many of the suggestions provided in this paper.

\section{References}

Ball, S. J. (2003). The teacher's soul and the terrors of performativity. Journal of Education Policy, 18(2), 215-228. doi: 10.1080/0268093022000043065 
Ball, S. J., Maguire, M., \& Braun, A. (2011). How Schools Do Policy: Policy Enactments in Secondary Schools. London: Routledge.

Coburn, C. E. (2004). Beyond Decoupling: Rethinking the Relationship Between the Institutional Environment and the Classroom. Sociology of Education, 77(3), 211-244. doi: $10.1177 / 003804070407700302$

Colebatch, H. K. (2009). Policy (3rd ed.). Maidenhead: Open University Press.

Cuban, L. (1995). The hidden variable: How organizations influence teacher responses to secondary science curriculum reform. Theory into practice, 34(1), 4-11.

DCSF/QCA. (2008). National Curriculum for England. http://curriculum.qca.org.uk/ key-stages-3-and-4/aims/index.aspx

Donnelly, J., Buchan, A. S., Jenkins, E. W., Laws, P., \& Welford, G. (1996). Investigations by order: policy, curriculum and science teachers' work under the Education Reform Act Driffield: Studies in Education.

Fensham, P. (2009). The link between policy and practice in science education: The role of research. Science Education, 93(6), 1076-1095.

Goodson, I. F. (2003). Professional Knowledge, Professional Lives. Maidenhead: Open University Press.

Jeffrey, B., \& Woods, P. (1998). Testing Teachers: The effect of school inspections on primary teachers London: Routledge.

Jenkins, E. (2013). Is a European vision for science education research a chimera? Studies in Science Education, 49(2), 265-272. doi: 10.1080/03057267.2013.823013

Kogan, M. (1975). Educational policy-making: A study of interest groups and parliament. London: George Allen and Unwin.

Kuiper, W., \& Berkvens, J. (Eds.). (2013). Balancing curriculum regulation and freedom across Europe. CIDREE Yearbook 2013. Enschede, the Netherlands: SLO.

Lunn, S., \& Solomon, J. (2000). Primary Teachers' thinking about the English National Curriculum for science: Autobiographies, warrants, and autonomy. Journal of Research in Science Teaching, 37(10), 1043-1056. doi: 10.1002/1098-2736(200012)37:10<1043::aidtea2>3.0.co;2-s

Millar, R., \& Osborne, J. (1998). Beyond 2000: Science education for the future. Retrieved April, 2010, from http://www.kcl.ac.uk/content/1/c6/01/32/03/b2000.pdf

Oates, T. (2011). Could do better: Using international comparisons to refine the National Curriculum in England. The Curriculum Journal, 22(2), 121-150.

Orrow-Whiting, M., Edwards, R., \& Slade, P. (2007). Keeping up the momentum: moderning the secondary science curriculum in England. School Science Review, 89(326), 27-29. 
Pring, R., Hayward, G., Hodgson, A., Johnson, J., Keep, E., Oancea, A., . . . Wilde, S. (2009). Education for All: The Future of Education and Training for 14-19 year olds. London \& New York: Routledge.

Roberts, D. A., \& Bybee, R. W. (2014). Scientific literacy, science literacy and science education. In N. Lederman \& S. K. Abell (Eds.), Handbook of Research on Science Education, Volume II (pp. 545-558): Routledge.

Ryder, J. (2015). Being professional: Accountability and authority in teachers' responses to science curriculum reform. Studies in Science Education, 51(1), 87-120.

Ryder, J., \& Banner, I. (2011). Multiple aims in the development of a major reform of the national curriculum for science in England. International Journal of Science Education, 33(5), 709-725.

Ryder, J., \& Banner, I. (2013). School Teachers' Experiences of Science Curriculum Reform. International Journal of Science Education, 35(3), 490-514.

Smith, D. V. (2011). One Brief, Shining Moment? The Impact of Neo-liberalism on Science Curriculum in the Compulsory Years of Schooling. International Journal of Science Education, 33(9), 1273-1288.

Wallace, C. S. (2012). Authoritarian science curriculum standards as barriers to teaching and learning: An interpretation of personal experience. Science Education, 96(2), 291310. doi: $10.1002 /$ sce. 20470

Wallace, C. S., \& Priestley, M. (2011). Teacher beliefs and the mediation of curriculum innovation in Scotland: A socio-cultural perspective on professional development and change.JournalofCurriculumStudies, 43(3),357-381.doi:10.1080/00220272.2011.563447

Jim Ryder

https://orcid.org/0000-0002-2741-0152

University of Leeds

School of Education

Professor of Science Education

Centre for Studies in Science and Mathematics Education

Leeds, UK

j.ryder@education.leeds.ac.uk

Submitted on 21st December 2016

Accepted on 12th January 2017

Published on 30th April 2017 